\title{
ウロキナーゼ,ヘパリン併用被覆カテーテルの 血栓形成阻害効果の検討
}

\author{
三上英智 ${ }^{* 1,3}$, 小林隆夫*2, 浦野哲盟 ${ }^{* 3}$
}

\begin{abstract}
表面にウロキナーゼとへパリン両薬剤を被覆した抗血栓性カテーテルを開発し，その性能をin vitro にて評価した。 ヒト全血を用いた改良 Chandler Loop 法において, ウロキナーゼあるいはへパリ ン単独被覆カテーテルよりも高い抗血栓性を示し, 25 日間のリンス後も保持された. Loop 内の血液 中の TAT, D ダイマーはリンス期間の延長とともに増加し, TAT 増加後は D ダイマー量も著増した。 プラスミン，トロンビンの合成基質 S-2251, S-2238 を用いて，カテーテル上のウロキナーゼおよび ヘパリン活性を測定した結果， 25 日間のリンス後もいずれの活性も保持されていることが確認され た。 カテーテルの表面にヘパリンとウロキナーゼの両者を被覆することにより, 抗凝固作用と線溶 活性化作用という二つの異なる血栓形成抑制作用が発揮され長期間抗血栓性が保たれることが明ら かになった。
\end{abstract}

Key words: anti-thrombotic catheter, urokinase, heparin, fibrinolysis, anticoagulation

\section{はじめに}

血管内留置カテーテル等の医療デバイスは, 現在の高度医療には不可欠となっているが，長 期間の体内留置に伴い惹起される血栓形成, 免 疫応答, 炎症反応等の異物反応が問題となる ${ }^{1)}$. 血管内留置カテーテルへの血栓付着は管腔閉塞 の原因になるだけでなく，塞栓症や感染症等の 重篤な合併症を引き起こすため, 様々な抗血栓 性素材のカテーテルが開発されてきだ)-5)，血 漿中のアンチトロンビンによるトロンビン及び 活性化 X 因子（FXa）活性阻害を強力に増強す るへパリン ${ }^{6)}$ や, 形成された血栓を溶解する線 溶系活性化酵素であるウロキナーゼ ${ }^{7)}$ 等が抗 血栓性中心静脈注射用カテーテル被覆に用いら れている.しかし未だ十分な機能を有するとは
言えず，留置中に血栓が付着したままの状態で 抜去される例がヘパリン被覆で $16.7 \%{ }^{8)}$, ウ口 キナーゼ被覆で $15.5 \%{ }^{9)}$ であったと報告されて いる. 今回, 表面にウロキナーゼとへパリンの 両者を被覆し，ヘパリンによる抗凝固作用とウ ロキナーゼによる線溶活性化作用という二つの 異なる血栓形成抑制作用の相加的ならびに相乗 的効果が期待できるカテーテルを開発し，その 抗血栓性を in vitro にて評価した.

\section{材料および方法}

\section{1. コーティング}

ポリウレタン製カテーテル，ポリ塩化ビニル 製マイクロプレートを試験基材とした。

メチルビニルエーテル無水マレイン酸共重合

${ }^{* 1}$ 日本シャーウッド株式会社 研究開発本部〔⿳亠丷厂 437-0004 静岡県袋井市友永 1217-1〕

Nippon Sherwood Medical Industries Ltd. R\&D Center〔1217-1 Tomonaga, Fukuroi, Shizuoka 437-0004, Japan〕

Tel: 0538-49-0011 Fax: 0538-49-1104 e-mail: hidetomo.mikami@covidien.com

*2 信州大学 医学部 保健学科

Shinshu University, School of Health Sciences

*3浜松医科大学 生理学第二講座

Hamamatsu University School of Medicine, Department of Physiology

受付日： 2007 年 4 月 1 日, 受理日：2008 年 1 月 31 日 
体 (International Specialty Products, USA), ポ リエーテルブロックアミド (Arkema, France) およびトリドデシルメチルアンモニウム塩 (Polysciences, USA）の混合溶液により基材 表面を被覆し，バインダー層を形成させた。 $60^{\circ} \mathrm{C} 3$ 時間の真空乾燥後, ヘパリンナトリウム (Diosynth, Netherlands), ウロキナーゼ（日本 ケミカルリサーチ, Japan) の混合溶液（へパ リンナトリウム : $1250 \mathrm{IU} / \mathrm{mL}$, ウロキナーゼ : $300 \mathrm{IU} / \mathrm{mL})$ に $5{ }^{\circ} \mathrm{C}$ に 24 時間浸漬させ，バ インダー層にヘパリンナトリウムおよびウロキ ナーゼを固定した（ヘパリンナトリウム，ウロ キナーゼ併用被覆コート：UK \& Hep coat $)^{10)}$. また，バインダー層を形成させた基材をそれぞ れヘパリンナトリウム溶液 $(1250 \mathrm{IU} / \mathrm{mL})$ ， ウ ロキナーゼ溶液 $(300 \mathrm{IU} / \mathrm{mL})$ に浸漬させて, 各単独被覆コート (Hep coat, UK coat $)^{11) 12)}$ を 作製した。

\section{2.ヒト全血を用いた凝固試験}

作製した各被覆カテーテルをクエン酸添加 ヒト全血でリンス後, 残存抗血栓活性を改良 Chandler Loop 法 $^{13)}$ により評価した $(\mathrm{n}=5)$.

1）リンス方法

$20 \mathrm{~cm}, 14 \mathrm{G}$ の被覆および非被覆ポリウレタ ン製カテーテルの両端をシリコーンゴム製カラ ーで連結固定しループを作成した。クエン酸 添加ヒト全血（3.8\%クエン酸ナトリウム水溶 液 $10 \%$ 容）をカテーテル内腔に注入し， $5{ }^{\circ} \mathrm{C} の$ 冷蔵庫内で, $5 \mathrm{rpm}$ で回転させた。2 時間ごと にカテーテル内腔の血液を捨て, 新たなクエン 酸ナトリウム添加ヒト全血を封入した。試験直 前にカテーテル内腔を蒸留水で洗浄し, 室温で 30 分間減圧乾燥した後下記の抗血栓性試験に 供した。血液リンスは最大 25 日間実施し，抗 血栓性の耐久性を評価した。

\section{2）抗血栓性試験}

リンス後の被覆および非被覆ポリウレタン製 カテーテルに健常成人男性から採取した新鮮全 血 $0.13 \mathrm{~mL}$ を注入した後，ドラムに固定し室温 $\left(24-26^{\circ} \mathrm{C}\right)$ にて，5 $\mathrm{rpm}$ で最長 4 時間回転させ た。 カテーテル内で血液が重力により落下し, ループ内を流動する速度条件として $5 \mathrm{rpm}$ を設 定した。カテーテル内の血液はドラムの回転に 伴い反対方向に流れるが，カテーテル内に血栓 が形成されることで，血栓形成に伴う内腔閉塞 により停止した。血液注入後完全に停止するま での時間を血栓形成時間とし，4時間後も流動 している場合は 4 時間以上とした。

\section{3. 凝固試験後のトロンビン - アンチトロン} ビン複合体（TAT)，D ダイマー測定

$20 \mathrm{~cm} ， 28$ Fr.の被覆および非被覆ポリウレ タン製カテーテルを凝固試験と同様に $3.8 \%$ ク エン酸ナトリウム水溶液添加（10\%） ウシ全 血にて最大 20 日間のリンス後，健常成人男性 から採取した新鮮全血を $4.0 \mathrm{~mL}$ 注入し，凝固 試験と同様に 4 時間室温にて血液とカテーテ ルとを接触させた。 4 時間後，カテーテル内 腔の血液を $18 \mathrm{G}$ 針付シリンジにて採取し， 3.8 \%クエン酸ナトリウム水溶液添加（10\%）後, $5{ }^{\circ} \mathrm{C}, 3000 \mathrm{rpm}$ にて 10 分間遠心分離し, 上清 約 $1 \mathrm{~mL}$ を TAT および D ダイマー測定の検体 とした. TATおよび D ダイマーは SRL Inc.に 依頼して ELISA 法にて測定した $(\mathrm{n}=2)$.

\section{4. ウロキナーゼ活性測定}

被覆および非被覆マイクロプレートを用い, 緩衝液による一定期間のリンス後, 残存ウロキ ナーゼ活性を発色性合成基質を用いて測定し た.

\section{1）リンス方法}

被覆および非被覆マイクロプレートに $0.1 \mathrm{M}$ Tris- $\mathrm{HCl}$ 緩衝液 $(\mathrm{pH}=7.4)$ を $100 \mu \mathrm{l}$ 添加し, $5{ }^{\circ} \mathrm{C}$ の冷蔵庫内で 24 時間震盪した。2 24 時間毎 に緩衝液を交換し，最大 25 日間リンスを継続 した。

\section{2）測定方法}

基材上に被覆されたウロキナーゼのリンス後 の残存活性はプラスミノーゲン活性化能により 
Thrombus

formation time

(h)

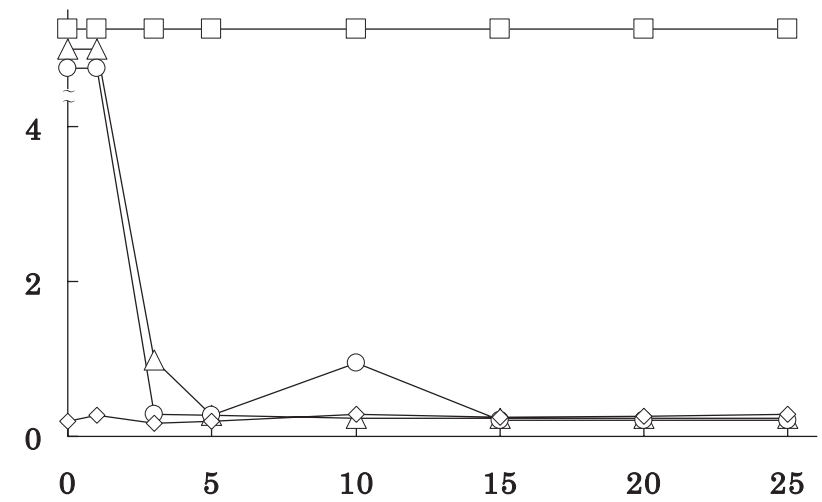

Rinsing days (d)

図 1 各被覆材料の Chandler Loop test による血栓形成時間の比較 UK \& Hep coat : $\square$, UK coat $: \triangle$, Hep coat $: \bigcirc$, non coat $: \diamond$ (mean value, $\mathrm{n}=5$ )

測定した。リンス後の被覆および非被覆マイク ロプレートのウェルにプラスミンの発色性合成 基質（S-2251，第一化学薬品，Japan）（最終濃 度 $0.3 \mathrm{mM}$ ）およびヒトプラスミノーゲン（新 鮮凍結血漿よりリジンセファロースを用いて精

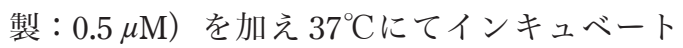
し，活性化されたプラスミンによるパラニトロ アニリンの遊離を $405 \mathrm{~nm}$ の吸光度の変化とし て測定し，ウロキナーゼ活性（ $\Delta \mathrm{ABS} 405 \mathrm{~nm}$ $\left.\times 10^{3} / \mathrm{min}\right)$ と定義した ${ }^{14)}(\mathrm{n}=8)$.

\section{5. ヘパリン活性測定}

被覆および非被覆マイクロプレートを用い, 緩衝液による一定期間のリンス後, 残存へパリ ン活性をアンチトロンビンによるトロンビン阻 害促進活性として発色性合成基質を用いて測定 した。

ウロキナーゼ活性測定と同様に試験に先立 ち $0.1 \mathrm{M}$ Tris- $\mathrm{HCl}$ 緩衝液 $(\mathrm{pH}=7.4)$ にてマイ クロプレートをリンスした. リンス後のマイ クロプレートに $3 \mu \mathrm{M}$ のアンチトロンビン (HYPHEN BioMed, France) $100 \mu \mathrm{L}$ を加え，室温 にて 1 時間インキュベートし基材上に被覆され
たヘパリンナトリウムとアンチトロンビンを反 応させた後, $0.1 \mathrm{M}$ Tris- $\mathrm{HCl}$ 緩衝液 $(\mathrm{pH}=7.4)$ にて 3 回洗浄した. $0.1 \mathrm{IU} / \mathrm{mL}$ のトロンビン （三菱ウエルファーマ, Japan） $95 \mu \mathrm{L}$ を加え室 温にて 30 分間インキュベートしトロンビンと アンチトロンビンとを反応させた後, トロンビ ンの発色性合成基質（S-2238，第一化学薬品） $5 \mu \mathrm{L}$ （4 mM） を加え, 試験開始後 5 分間の波 長 $405 \mathrm{~nm}$ の吸光度変化を測定した $(n=8)$ 。ア ンチトロンビン未添加にて測定した単位時間あ たりの吸光度変化（ $\Delta \mathrm{ABS} 405 \mathrm{~nm} / \mathrm{min}$ ）をト ロンビン $100 \%$ 活性とし，アンチトロンビン添 加時の吸光度変化を残存トロンビン活性とし た. 前者と後者の差を前者で除したものをトロ ンビン活性阻害率すなわちへパリン活性（\%) と定義した。

測定したウロキナーゼ，ヘパリン活性は Steel-Dwass 法にて統計学的に有意差を検討し た.

\section{結 果}

\section{1.ヒト全血を用いた凝固試験}

UK \& Hep coat では，全てのリンス期間（最 


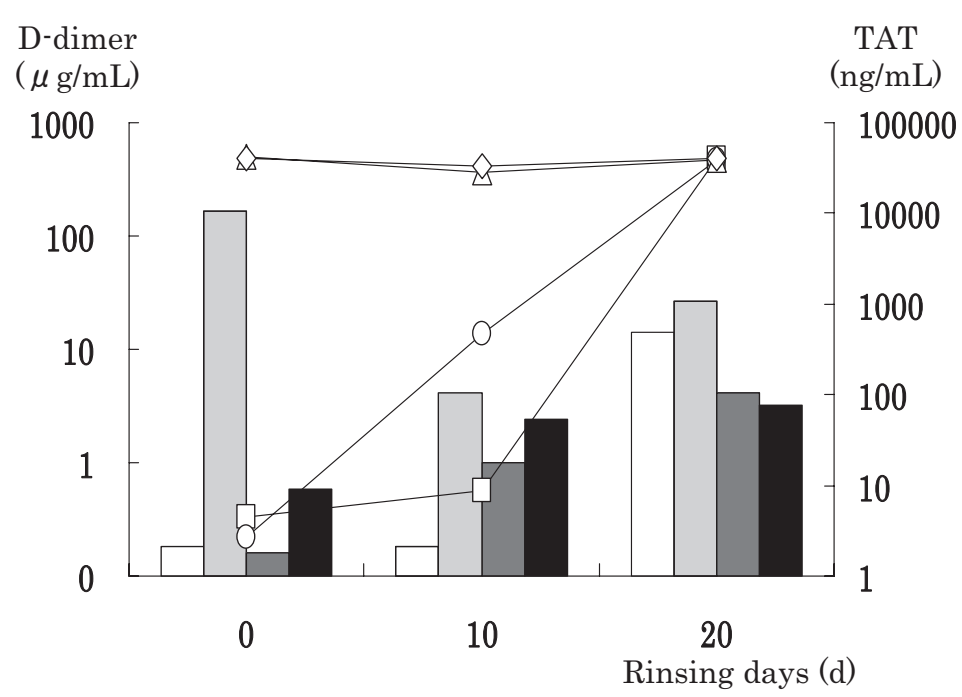

図 2 UK \& Hep 被覆材用の Chandler Loop test 後の血液中 TAT および D ダイ マー值

折れ線グラフ (TAT 值) : UK \& Hep coat $: \square$, UK coat $: \triangle$, Hep coat $: \bigcirc$, non coat : $\diamond$

棒グラフ (D ダイマー值) : UK \& Hep coat : —, UK coat : —, Hep coat :

, non coat : (mean value, $\mathrm{n}=2$ )

長 25 日間）の検体において試験開始 4 時間後 もループ内の血液の流動性は保たれた（図 1).

UK coat, Hep coatでは，リンス期間が 0 か ら 1 日ではUK\&Hep coat と同様に試験開始 4 時間後も血液の流動性は保たれたが，リンス期 間が 3 日以上になると，試験開始 20 分以内に ループ内の血液が凝固した。未処理のカテーテ ルでは全てのリンス期間の検体において試験開 始後 20 分以内にループ内の血液が凝固した.

\section{2. 凝固試験後の TAT，D ダイマー測定}

ヒト全血を用いた凝固試験開始 4 時間後の 血液中の TAT は，リンス 0 日において, UK \& Hep coat 及 び Hep coat では $4.50 \mathrm{ng} / \mathrm{mL}$, $2.70 \mathrm{ng} / \mathrm{mL}$ と低值を示したが, UK coat, noncoat では $41400 \mathrm{ng} / \mathrm{mL} ， 40850 \mathrm{ng} / \mathrm{mL}$ と高值を 示し, UK \& Hep coat, Hep coatでは被覆した ヘパリンにより凝固系活性化が抑制されている ことが示された。その際の D ダイマーはそれ ぞれ $0.18 \mu \mathrm{g} / \mathrm{mL}, 0.16 \mu \mathrm{g} / \mathrm{mL}, \quad 163.75 \mu \mathrm{g} / \mathrm{mL}$,
$0.59 \mu \mathrm{g} / \mathrm{mL}$ であり, TAT 高值を示した UK coat及び non-coat で高值を示した。 UK coat で はnon-coatに比し極めて高值を示し，被覆し たウロキナーゼにより産生されたフィブリンが 効率的に溶解されていることが示された。 3.8 \%クエン酸ナトリウム添加ウシ全血を用いた リンスにより UK \& Hep coat, Hep coat の TAT 值も上昇を示し，それに伴い D ダイマー值も 上昇を示した。 UK \& Hep coat の方が上昇の程 度は大きく, UK coatと同様に形成されたフィ ブリンを効率的に溶解していることが示された (図 2).

\section{3. ウロキナーゼ活性測定}

UK \& Hep coat, UK coatにおいて, コー ト中のウロキナーゼ活性の初期值（ $\Delta \mathrm{ABS}$ $\left.405 \mathrm{~nm} \times 10^{3} / \mathrm{min}\right)$ はそれぞれ $6.08 \pm 0.93$, $5.00 \pm 1.28$ であったが，リンス期間の延長と 共にその值は低下した。しかしリンス 25 日後 においてもそれぞれ $1.98 \pm 0.38,1.14 \pm 0.11$ 


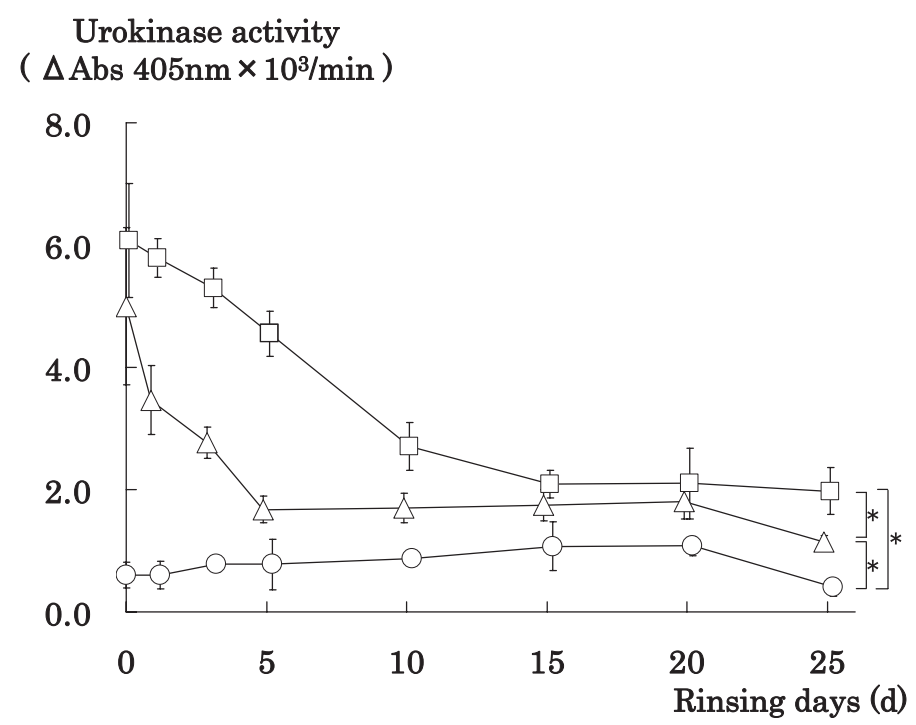

図 3 リンス後のウロキナーゼ残存活性

プラスミンの発色性合成基質 S-2251 を用い，基材上に残存するウ口 キナーゼのプラスミノーゲン活性化能を測定した。

UK \& Hep coat, UK coat ともにリンスにより残存するウロキナーゼ の活性に低下が認められたが，リンス 25 日後も Hep coat と比較し 有意に高い活性を示した $(\mathrm{p}<0.01$, Steel-Dwass 法 $)$.

UK \& Hep coat : $\square$, UK coat : $\triangle$, Hep coat : $\bigcirc$ (mean value \pm S.D., $n=8$ )

であり, ウロキナーゼを含有しない Hep coat $(0.40 \pm 0.14)$ と比較して有意に高值を示した ( $\mathrm{p}<0.01)$. Hep coat においてウロキナーゼ活 性は $0.40 〜 1.31$ を示し，対照（リンス未実施 の未被覆マイクロプレート）における若干の合 成基質の水解とほぼ同等であった（図 3).

\section{4. ヘパリン活性}

UK \& Hep coat, Hep coat においてへパリン 活性の初期值はそれぞれ $91.3 \pm 4.8 \% ， 91.4 \pm$ $5.2 \%$ であたが，リンス期間の延長と共にそ の值が低下する傾向が観られた。しかし25日 間のリンス後においてもそれぞれ $61.9 \pm 15.3$ $\%, 59.3 \pm 6.2 \%$ と UK coat $(29.7 \pm 9.1)$ に比 し有意に高い活性が維持されていた。 $(\mathrm{p}<0.01)$ アンチトロンビンによるトロンビンの阻害効 果をへパリン活性と定義したため，ヘパリンを 含有していない UK coatに拈いて9〜35\%，リ ンス未実施の未被覆において $2.4 \pm 2.9 \%$ の パリン活性が示された。これは非特異的に結合
したアンチトロンビンによるへパリン非依存性 のトロンビン阻害活性によるものと考えられた (図 4).

考察

血管内には血栓形成を抑制する様々な生理的 な機構が存在する，主として血管内皮細胞の抗 凝固活性に依存しており，アンチトロンビンの 抗トロンビン活性並びに抗 Xa 活性を増強する ヘパラン硫酸等のプロテオグリカンと, トロン ビンの凝固活性を抗凝固活性に転換するトロン ボモジュリンに依る ${ }^{15}$. 血管内皮はまた組織型 プラスミノーゲンアクチベーター（tPA）を分 泌して高い線溶活性を維持することにより抗血 栓性を保つ ${ }^{15)}$ tPA あるいはプラスミノーゲン の遺伝子欠損動物が血管内皮障害により容易に

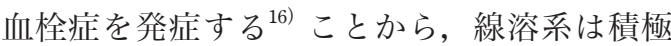
的に過剩血栓形成を抑制していると考えられ る. 


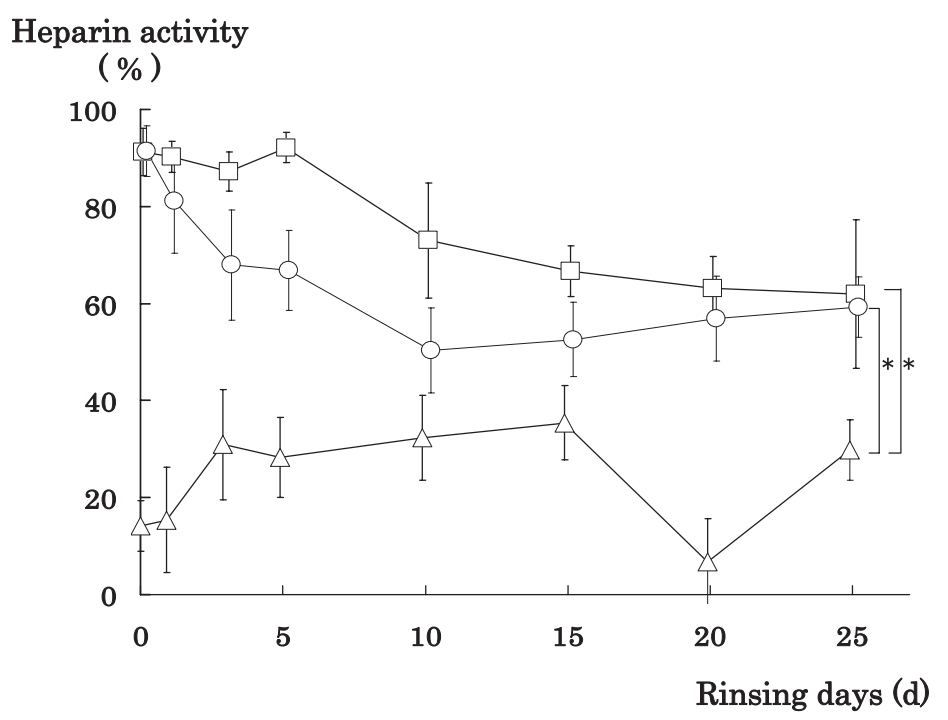

図 4 リンス後のヘパリン残存活性

トロンビンの発色性合成基質 S-2238 を用い，基材上に残存するへパリ ンのトロンビン活性阻害能を測定した.

UK \& Hep coat, Hep coat ともにリンスにより残存するへパリンの活性 に低下が認められたが, リンス 25 日後も Hep coat と比較し有意に高 い活性を示した（(p<0.01, Steel-Dwass 法).

UK \& Hep coat : $\square$, UK coat : $\triangle$, Hep coat : $\bigcirc$ (mean value \pm S.D., $n=8$ )

今回我々は血管内力テーテル留置の際に問題 となる表面上の血栓形成に対処するため，血管 内皮細胞の抗血栓機能を模してへパリンとウロ キナーゼを併用被覆したカテーテルを作製しそ の抗血栓機能を評価した。 ヒト全血を用いた凝 固試験結果が示すようにUK \& Hep coat は，各 単独コートに比して抗血栓性を長期間維持する ことが明らかとなった。ウロキナーゼとへパリ ンは, 線溶活性化作用と抗凝固作用という二つ の異なる機序により血栓形成を抑制することか ら，両者を被覆したカテーテルは長期間抗血栓 性を発揮すると考えられる。

ヒト全血を用いた凝固試験後の血中 TAT，D ダイマーは, UK \& Hep coat, Hep coatにおい てヘパリンの抗凝固活性によりリンス 0 日にお いて低值を示した.リンスによるへパリンの活 性低下に伴い $\mathrm{TAT}^{17)}$ が増加した 20 日後に UK \& Hep coat の D ダイマー ${ }^{18)}$ が著増しており, 抗凝固活性と線溶活性が協調的に血栓形成を阻 害していると考えられた。
被覆マイクロプレートを用いたウロキナー ゼ，ヘパリン活性測定結果より，両薬剤の活性 はリンスによる低下するが，25日後も残存し ていることが確認された。

併用被覆と比較し単独被覆においてそれぞれ の活性低下が顕著であったことより，両者の共 存により各々の薬剤の活性が維持されている可 能性が示唆された。ウロキナーゼはクリング ル構造を介してヘパリンと結合し，そのプラス ミノーゲン活性能を高めることが知られてい る ${ }^{19)}$ 。この特異結合により長期間にわたり各々 の薬剤が残存する可能性や，ウロキナーゼの残 存活性が高く示された可能性がある。本検討で はその特定にはいたらなかつたが，これらの事 実もヒト全血を用いた凝固試験において併用被 覆が単独被覆と比較し長期に抗血栓性を維持で きる原因となっていると推察される。

上記に加え, ヘパリン単独被覆カテーテルで は被覆中へパリンの活性低下により形成され た血栓が除去されず，析出血栓がヘパリン被覆 
面を覆うため，ヘパリンアンチトロンビン複合 体による抗トロンビン並びに抗 Xa 活性が消失 するため，併用被覆カテーテルと比較し早期に 抗血栓性が消失したと考えられた。同様にウロ キナーゼ単独被覆カテーテルではヘパリンによ る抗凝固活性が無いためウロキナーゼの溶解活 性を上回る血栓が形成されウロキナーゼ被覆面 を覆うため, 早期に抗血栓性が消失したものと 考えられた。更に，血栓形成に伴い血小板から 多量に放出される，へパリン活性中和因子（血. 小板第 4 因子 $)^{20)}$ およびウロキナーゼの特異 的なインヒビターである Plasminogen activator inhibitor 1 (PAI-1) $)^{21)}$ も血栓付着に伴うへパリ ンあるいはウロキナーゼの活性消失に関与する と考えられる.

両者の併用被覆カテーテルではヘパリンによ る血栓形成抑制と，ウロキナーゼによる生成微 量血栓の迅速な溶解により，管腔内の血栓塊の 形成が長期間抑制されたと考えられた。

以上ウロキナーゼとへパリンは，抗凝固作用 と線溶活性化作用という二つの異なる機序によ り血栓形成を抑制し，それぞれの活性が単独被 覆と比較し長期間維持されることから，両者を 被覆したカテーテルは長期間抗血栓性を発揮す ることが証明された。これは生理的条件下で血 管内でおこる血栓形成及び溶解機構に類似して おり，理にかなった抗血栓性であると考える。 両薬剤の併用被覆カテーテルの抗血栓性カテー テルとしての有用性が in vitro の系で実証され た。

\section{文献}

1）石橋一彦：生体材料の最近の進歩, 4. 抗血栓性材料の新 展開,外科 $61: 132-135,1999$.

2）杉立彰夫, 洪性徳, 今岡真義, 大城孟, 神前五郎, 高木邦彦：
固定化 Urokinase の抗血栓性, 血液と脈管 9 : 504-509, 1978.

3）中谷武嗣, 西村 隆, 江屋一洋, 戸田宏一, 脇坂佳成, 武和 能明, 宮崎幸治, 馬場雄造, 増澤 徹, 巽 英介, 妙中義之, 高野久輝, 佐藤正喜, 柏原 進 : ヘパリン化ポリウレタ ンを用いた補助人工心臓用血液ポンプの検討, 人工藏器 26: 86-92, 1997.

4）毛井純一, 和田壽郎, 横山正義, 兼安秀人, 板岡俊成, 田原 士郎, 斉藤真知子, 桜井靖久, 岡野光夫 : 抗血栓材料による 静脈内留置カテーテルの開発, 人工㵴器 $16: 1392-1402$, 1987.

5）田中 賢: 人工臟器の表面を生体適合化するマテリアル, Bio Industry $20: 59-70,2003$.

6) Lindahl U, Kjellen L : Heparin or heparansulphate - what is the difference. Thrombosis and Haemostasis $66: 44-48$, 1991.

7）小嶋聡一: uPA の基礎と臨床,一瀬白帝, 編集, 四説血栓・ 止血・血管学. 東京, 中外医学社, 2005, 555-566.

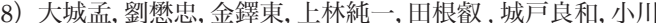
嘉誉, 森武貞 : ウロキナーゼ固定化エバテートカテーテル の臨床検討, 比較試験の成績, 人工藏器 $5: 195-200,1986$

9）浦野博秀: 抗血栓性カテーテル臨床使用経験,集中治療学 会, 1984 .

10）公開特許広報: 特開 2005-103238

11）杉立彰夫, 高木邦彦, 向井清, 洪性徳, 今岡真義, 大城孟, 神 前五郎 : 線溶酵素 urokinase 固定化の試み, The Journal of Medical Enzymology 2 : 295-303, 1997.

12）公開特許広報: 特開 2000-202031.

13) Chandler $A B$ : In vitro throbmotic coagulation of the blood. In vitro thrombotic coagulantion $7: 110-114,1958$.

14）浦野哲盟：合成基質を用いた䤉素反応の解析，血液・腫 瘍科 $40: 273-281,2000$.

15）鈴木優子, 浦野哲盟: 血管内皮細胞による血栓形成・線溶 の調節の基䃈, 分子血管病 $6: 13-18,2005$.

16）浦野哲盟：線溶機序, 池田康夫, 監修, 内山真一郎, 後藤信 哉, 重松宏, 半田誠, 編集, 血栓症ナビゲーター. 大阪, メデ イカルレビュー社, 2006, 100-101.

17）岡嶋研二 : アンチトロンビン,トロンビン - アンチトロ ンビン複合体, 中井利昭, 尾崎由基男, 小室一成, 小田原 雅人, 野村文夫, 編集, 検査値のみかた. 東京, 中外医学社, 2006, 454-456.

18）浦野哲盟：FDP, D ダイマー, 中井利昭, 尾崎由基男, 小室 一成, 小田原雅人, 野村文夫, 編集, 検査值のみかた. 東京, 中外医学社, 2006, 463-466.

19) Stephens RW, Bokman AM, Myöhänen HT, Reisberg T, Tapiovaara H, Pedersen N, Grøndahl-Hnasen J, Llinás M, Vaheri A : Heparin Binding to the Urokinase Kringle Domain. Biochemistry $31: 7572-7579,1992$.

20）鈴木英紀 : 血小板内顆䊉々生理活性物質, 池田康夫, 丸山 征郎, 監修, 血小板生物学. 大阪, メディカルレビュー社, 2004, 111-118.

21）井原勇人, 浦野哲盟: プラスミノーゲン・アクチベータ ー・インヒビターの基礎と臨床, 一瀬白帝, 編集, 図説血 栓・止血・血管学.東京, 中外医学社, 2005, 606-613。 


\title{
Evaluation of anti-thrombotic efficacy of newly developed catheter coated with urokinase together with heparin
}

\author{
Hidetomo MIKAMI ${ }^{* 1,3}$, Takao KOBAYASHI ${ }^{* 2}$, Tetsumei URANO*3
}

Key words: anti-thrombotic catheter, urokinase, heparin, fibrinolysis, anticoagulation

We developed an anti-thrombotic catheter, whose surface was coated with both urokinase and heparin, and evaluated its anti-thrombotic potential. A modified Chandler loop test revealed that the catheter kept high anti-thrombotic capacity even after 25 days' rinsing with human citrated whole blood. Activities of urokinase and heparin measured by synthetic substrate for plasmin and thrombin respectively were reserved even after 25 days' rinsing. Both TAT and D-dimer in blood in the modified Chandler loop increased gradually in a time dependent manner, which suggests that anti-thrombotic function of the catheter were reserved for the evaluated period by two distinct mechanisms of anticoagulation by heparin and of fibrinolysis by urokinase. These ex-vivo studies confirmed the long-lasting anti-thrombotic efficacy of anti-thrombotic catheter coated with both urokinase and heparin, and suggest promising usefulness of its clinical application. 